\title{
Potensi Risiko Kesehatan Manusia Akibat Konsumsi Perna viridis yang Mengandung Kadmium
}

\author{
Farhan Ghifari*, Adi Santoso, Jusup Suprijanto \\ Departemen Ilmu Kelautan, Fakultas Perikanan dan Ilmu Kelautan, Universitas Diponegoro \\ JI. Prof. H. Soedarto S.H, Tembalang, Semarang, Jawa Tengah 50275 Indonesia \\ Corresponding author, e-mail : farhanghifari2@gmail.com
}

\begin{abstract}
ABSTRAK: Tambak Lorok merupakan salah satu Kawasan yang padat penduduk dan terdapat banyak aktivitas seperti industri, Pelabuhan dan menjadi pusat penjualan hasil laut dengan adanya TPI Tambak Lorok. Limbah hasil kegiatan industri, Pelabuhan dan rumah tangga diduga menyebabkan terjadinya pencemaran logam berat kadmium (Cd) di perairan dan mempengaruhi biota laut seperti kerang hijau ( Perna viridis). Penelitian ini bertujuan untuk mengetahui kandungan logam berat $\mathrm{Cd}$ pada air, sedimen, dan kerang hijau (Perna viridis) serta mengetahui potensi risiko Kesehatan yang timbul apabila mengkonsumsi kerang hijau (Perna viridis) tersebut. Penelitian ini dilaksanakan pada bulan Desember 2020, Januari 2021, dan Maret 2021 dengan metode deskriptif. Analisis kandungan logam berat kadmium (Cd) pada air, sedimen dan kerang hijau dilakukan di Laboratorium Teknik Lingkungan Universitas Diponegoro dengan metode AAS (Atomic Absorption Spectrophotometer). Hasil analisis kandungan logam berat pada air berkisar $<0,001-0,696 \mathrm{mg} / \mathrm{L}$, sedimen $<0,001-1,931 \mathrm{mg} / \mathrm{kg}$, dan jaringan lunak kerang hijau (Perna viridis) 0,070-1,693 mg/kg. Berdasarkan perhitungan Estimasi Asupan Harian (EDI) untuk laki-laki dewasa menunjukkan nilai berkisar 0,000026-0,000626 mg/kg/hari dan pada perempuan dewasa berkisar 0,000035-0,000835 $\mathrm{mg} / \mathrm{kg} /$ hari. Sedangkan nilai tingkat risiko (THQ) untuk laki-laki dewasa menunjukkan nilai berkisar 0,026-0,626. Dan untuk perempuan berkisar 0,035-0,835. Dari hasil penelitian ini dapat disimpulkan bahwa di perairan Tambaklorok Semarang di air, sedimen dan jaringan lunak kerang hijau sudah terindikasi tercemar logam berat $\mathrm{Cd}$. Kewaspadaan mengkonsumsi kerang hijau perlu dilakukan meskipun dari aspek kesehatan berdasarkan perhitungan EDI dan THQ masih aman dan belum menunjukkan tingkat bahanya.
\end{abstract}

Kata kunci: Kadmium; Kerang hijau; Logam berat; Tambak Lorok

\section{Heavy Metal Content of Cadmium in Water, Sediment, and Perna viridis in Tambak Lorok Waters and Potential Risks to Human Health}

\begin{abstract}
Tambak Lorok Semarang is one of the densely populated areas. There are many activities such as industry, ports, and becoming a center for selling marine products with the Tambak Lorok TPI. The waste resulted is suspected of causing heavy metal cadmium (Cd)pollution in the waters and affecting marine biota such as green mussels (Perna viridis). This study aimed to determine the content of $\mathrm{Cd}$ in water, sediment, and green mussels (Perna viridis) and to determine the potential health risks that arise when consuming the mussels. The field study occurred in December 2020, January 2021, and March 2021 with a descriptive method. Analysis ofthe Cd content was conducted at the Environmental Engineering Laboratory Diponegoro Universityby the AAS (Atomic Absorption Spectrophotometer) method. The results of the heavy metalcontent in water, sediment, and mussels' soft tissue respectively ranged from $<0.001-0.696 \mathrm{mg} / \mathrm{L},<0.001$ $1.931 \mathrm{mg} / \mathrm{kg}$, and $0.070-1.693 \mathrm{mg} / \mathrm{kg}$. The Estimated Daily Intake (EDI) for adult males' values ranged from $0.000026-0.000626 \mathrm{mg} / \mathrm{kg} / \mathrm{day}$, and for adult females from 0.000035-0.000835 $\mathrm{mg} / \mathrm{kg} /$ day. While the value of the risk level (THQ) for adult males showed a value ranging from 0.026-0.626. And for females, it ranged from 0.035 to 0.835. It showed that Cd contaminated the water, the sediment, and soft tissue of green mussels in Tambaklorok Waters. Even though a health aspect is still safe and has not shown the danger, people have to be precaution in consuming the mussels.
\end{abstract}

Keywords: Cadmium; Green mussels; Heavy metals; Tambak Lorok 


\section{PENDAHULUAN}

Kawasan Tambak Lorok memiliki daerah dengan nama Kampung Tambak Lorok yang memiliki fungsi utama sebagai wilayah pemukiman, pertambakan dan sebagai tempat perekonomian hasil perikanan. Kampung Tambak Lorok berlokasi cukup strategis yaitu berdeketan dengan area fungsional kota utama Semarang misalnya area pelabuhan, pergudangan, pusat kota lama, Stasiun Kereta Api Tawang (Wulanningrum dan Jayanti, 2016). Banyaknya kegiatan di sekitar Tambak Lorok diduga menyebabkan pencemaran logam berat pada perairan. Logam berat yang terkandung dalam perairan tersebut berasal baik itu dari limbah padat, cair, dan gas yang pembuangannya berakhir di perairan Tambak Lorok dan terakumulasi dengan berjalannya waktu (Triantoro et al., 2017). Salah satu logam berat yang mencemari perairan adalah logam berat kadmium (Cd). Menurut Noviansyah et al. (2021), logam berat Cd di perairan berasal dari lingkungan sekitar Tambak Lorok yang merupakan kawasan pelabuhan dan juga PLTU serta terdapat beberapa sungai yang muaranya menuju perairan Tambak Lorok. Sumber lain yang dapat menyebabkan pencemaran logam berat $\mathrm{Cd}$ yaitu dari kegiatan pertanian dan peternakan, pelapisan logam, tumpahan minyak/oil spill, plastik, batu bara, baterai atau aki, dan endapan sampah (Rachmaningrum et al., 2015). Kadmium dalam perairan dapat berbahaya karena sifat dari kadmium adalah elemen toksik yang akan menjadikan ketidakseimbangan ekologi perairan dan kelangsungan hidup yang berlangsung di perairan tersebut (Mamoribo et al., 2015).

Menurut Khusnia et al. (2019), Pencemaran logam berat yang terjadi pada perairan dapat menyebabkan terjadinya penumpukan logam berat pada tubuh biota. Salah satu biota yang saat ini telah banyak dibudidayakan yaitu kerang hijau. Kerang hijau adalah salah satu komoditas yang sudah banyak dikenal dan menjadi konsumsi pangan. Kerang hijau juga merupakan salah satu biota yang banyak ditemukan pada perairan Tambak Lorok. Kerang hijau termasuk ke dalam hewan yang bersifat filter feeder. Hewan dengan sifat ini memiliki pergerakan yang rendah dan cenderung tinggal menetap sehingga lebih mudah tercemar oleh zat pencemar seperti logamberat. Logam berat di perairan masuk ke dalam tubuh biota melalui insang, mulut dan kulit yang selanjutnya diserap oleh saluran pencernaan. Logam berat tersebut tertimbun dalam jaringantubuh biota terutama dalam hati dan ginjal (Eshmat et al., 2014). Logam Cd termasuk kedalam logam non esensial bersama dengan timbal $(\mathrm{Pb})$, Merkuri $(\mathrm{Hg})$, arsenic ( $\mathrm{Ar})$. Logam non esensial tersebut tidak memiliki fungsi bagi tubuh manusia melainkan hanya dapat menjadi toksik dan racun (Adhani dan Husaini, 2017). Apabila logam berat telah memasuki lingkungan, kerusakan tidak hanya terjadi pada perairan dan biota, tetapi dapat juga menyebabkan masalah Kesehatan terhadap manusaia. Penelitian ini bertujuan untuk mengetahui kandungan logam berat Cd pada air, sedimen, dan kerang hijau (Perna viridis) serta mengetahui potensi risiko Kesehatan yang timbul apabila mengkonsumsi kerang hijau (Perna viridis) tersebut

\section{MATERI DAN METODE}

Materi yang digunakan dalam penelitian ini adalah sampel air, sedimen dan kerang hijau Perna viridis) yang diambil dari perairan Tambak Lorok, Kota Semarang (Gambar 1). Pengamatan dilapangan berupa parameter kualitas lingkungan digunakan sebagai data pendukung penelitian. Parameter kualitas lingkungan yang diukur yaitu parameter fisika dan kimia berupa suhu, salinitas, DO (Dissolved Oxygen), pH, kecerahan dan data curah hujan. Metode penelitian yang digunakan adalah metode deskriptif yaitu untuk dapat melukiskan gambaran secara sistematis, faktual, akurat, terpercaya yang sesuai dengan kondisi asli dari Perairan Tambak Lorok, Kota Semarang serta hubungan dari fenomena yang diteliti. Penelitian menggunakan metode ini untuk dapat memudahkan kondisi dan situasi kasus tertentu dan pada waktu tertentu (Andayani et al., 2020).

Metode pengambilan sampel yang digunakan dalam penelitian yakni menggunakan metode purposive sampling yaitu menetapkan ciri khusus yang sesuai dengan tujuan dari penelitian dengan memperhatikan jarak antar lokasi. Menurut Sugiyono (2017), Purposive SamplingMethod digunakan dalam penelitian disebabkan teknik ini mempertimbangkan penentuan sampel tertentu karena sampel-sampel yang ada tidak semuanya memiliki kriteria yang dibutuhkan dari tujuan penelitian. Penentuan stasiun pengambilan sampel didasarkan dari keberadaan logamberat kadmium (Cd) dan juga keberadaan kerang hijau (Perna viridis). Lokasi pengambilan sampelterdiri dari 3 stasiun 
stasiun 1 berada di muara sungai Banjir Kanal Timur, stasiun 2 berada pada tambak bandeng dan stasiun 3 di Pelabuhan dan 1 stasiun teridiri dari 3 titik (Gambar 1). Pengambilan sampel dilakukan pada bulan Desember 2020, Januari 2021, dan Maret 2021. Sampel air diambil menggunakan botol Nansen pada kedalaman $30-50 \mathrm{~cm}$. Pengambilan sampel sedimen menggunakan alat sediment grab. Dan sampel kerang hijau (Perna viridis) diambil secara langsung dengan metode hand picking atau diambil menggunakan tangan (Kama et al., 2020). Sampel yang sudah diambil tersebut kemudian dilakukan analisis kandungan logam berat kadmium (Cd) di Laboratorium Teknik Lingkungan Universitas Diponegoro dengan metode AAS (Atomic Absorption Spectrophotometer) (Triantoro et al., 2017).

Analisis faktor biokonsentrasi digunakan untuk mengetahui seberapa besar kerang hijau dalam mengakumulasi logam berat kadmium (Cd) dari perairan. Faktor biokonsentrasi dihitung menurut Astari et al. (2021). Hasil dari perhitungan faktor biokonsentrasi (FBK) antara kerang dan sedimen serta kerang dan air dilanjutkan dengan mengklasifikasikan kategori akumulasi logam berat berdasarkan La Grega et al. (2001) sebagai berikut: Akumulasi rendah = FBK<100; Akumulasi sedang $=100<$ FBK $\leq 1000 ;$ Akumulasi tinggi $=$ FBK $>1000$

Estimasi asupan harian atau Estimated Daily Intake (EDI) adalah suatu perkiraan estimasi asupan logam berat yang masuk ke dalam tubuh manusia melalui konsumsi makanan pada setiap harinya (Rayyan et al., 2019). Berat badan menggunakan asumsi laki-laki dewasa dan perempuan dewasa (Nuraini et al., 2017). Estimasi paparan makanan terhadap logam berat dapat dihitung menggunakan rumus berikut (Departemen kesehatan, 2012).

Penilaian THQ bertujuan untuk mengevaluasi kemungkinan dampak buruk yang timbul akibat mengkonsumsi makanan laut yang tercemar oleh suatu jenis logam.Nilai bahaya target atau Targer Hazard Quotient makanan terhadap logam berat dapat dihitung menggunakan rumus berikut (Soegianto et al., 2020).

\section{HASIL DAN PEMBAHASAN}

Berdasarkan pengukuran parameter kualitas perairan yang dilakukan di Perairan Tambak Lorok pada bulan Desember 2020, Januari 2021, dan Maret 2021 pada setiap stasiun didapatkan hasil yang disajikan pada Tabel 1. Hasil analisis kandungan logam berat kadmium dalam air memiliki nilai yang beragam setiap bulannya. Kandungan logam berat kadmium dalam air dapat dilihat pada Tabel 2.

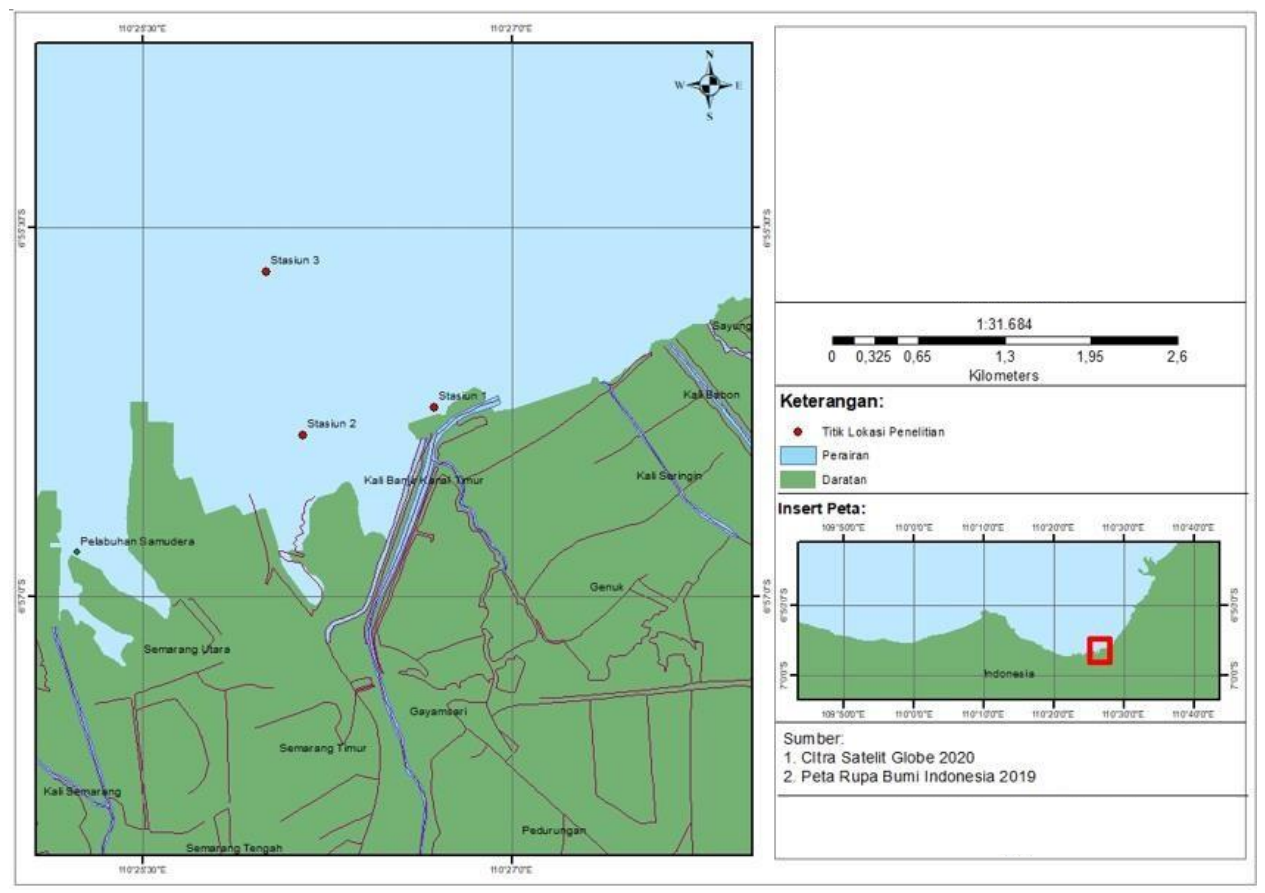

Gambar 1. Lokasi Penelitian 
Hasil analisis kandungan logam berat Cd dalam air cenderung lebih besar pada bulan Januari 2021, hal ini diduga karena perbedaan cuaca pada saat pengambilan sampel air. Sampel air yang diambil pada bulan Januari 2021 telah memasuki musim penghujan sehingga partikel partikel yang terendapkan terangkat oleh arus ke kolom perairan. Menurut Sundra (2006), pada saat musim hujan tiba terdapat dua kemungkinan yang akan terjadi, air hujan akan mengencerkan bahan pencemar sehingga kadarnya menjadi lebih kecil atau perairan laut mendapat masukan yang lebih besar yang berasal dari aliran-aliran sungai yang mengangkut limbah logam berat. Hal ini sejalan dengan Nurhayati dan Putri (2019), yang mengatakan kandungan logam berat pada perairan saat musim hujan dipengaruhi oleh faktor fisik seperti arus yang membawa partikel- partikel sedimen dari dasar menuju ke kolom perairan. Pada bulan Januari 2021 curah hujan sebesar 300,8 mm (BMKG, 2021). Analisis kandungan logam berat kadmium pada air yangdilakukan pada bulan Desember 2020 didapat hasil <0,001 pada stasiun 1 dan stasiun 2 titik 1 dan 2, hal tersebut diasumsikan bahwa logam berat kadmium $(\mathrm{Cd})$ yang tersebar pada perairan tersebut masih tergolong rendah sehingga tidak terdeteksi (Anam et al., 2019). Hasil lainnya menunujukkan nilai yang telah melampaui nilai ambang batas yang di tetapkan oleh Kementrian Lingkungan Hidup No. 51 Tahun 2004 yaitu sebesar $0,01 \mathrm{mg} / \mathrm{L}$ untuk perairan pelabuhan dan $0,001 \mathrm{mg} / \mathrm{L}$ untuk biota laut.

Menurut Prihati et al. (2020), suhu pada perairan dapat secara langsung atau tidak langsung mempengaruhi kondisi perairan. Suhu secara langsung dapat mempengaruhi aktivitas organisme seperti pertumbuhan dan metabolisme, sedangkan pengaruh suhu secara tidak langsung akan mempengaruhi oksigen terlarut (DO). Berdasarkan baku mutu yang ditetapkan hasil pengukuran suhu masih berada dibatas normal. Sedangkan pengukuran DO didapat pada stasiun 1 setiap bulannya memiliki nilai yang berada dibawah baku mutu ( $>5 \mathrm{mg} / \mathrm{l})$, diduga nilai DOyang rendah karena letaknya yang berada dimuara sungai. Menurut Patty (2013), kadar DO diperairan berkaitan erat dengan kekeruhan air laut, stasiun 1 yang merupakan daerah muara sungai memiliki tingkat kekeruhan yang tinggi dapat dilihat pada tabel 3 tingkat kecerahan stasiun 1 tergolong rendah dibandingkan stasiun lainnya. Nilai $\mathrm{pH}$ yang didapat dari hasil pengukuran kualitas perairan diketahui stasiun 1 memiliki nilai yang berada dibawah baku mutu perairan. Nilai pH berkaitan dengan nilai $\mathrm{DO}$ dimana jika nilai $\mathrm{pH}$ maka nilai $\mathrm{DO}$ juga rendah. nilai $\mathrm{pH}$ yang rendah pada stasiun 1 karena lokasinya yang berdekatan dengan muara sungai. Hal ini juga diperkuat oleh Susana (2009), dimana nilai pH akan semakin tinggi apabila semakin ke arah laut lepas. Menurut Effendi (2003), sungai membawa material-material organik yang terakumulasi padamuara sungai sehingga pHnya menjadi rendah.

Salinitas pada perairan berperan penting untuk menunjang kehidupan biota di dalamnya. Menurut Triantoro et al. (2017), nilai salinitas pada perairan dipengaruhi oleh beberapa faktor diantaranya pola sirkulasi air, penguapan, curah hujan dan aliran sungai (kecepatan arus). Salinitas yang didapat dari hasil pengukuran pada bulan Desember 2020, Januari 2021, dan Maret2021 pada 3 stasiun diketahui nilai terendah salinitas pada air laut yaitu pada stasiun 1, hal ini diduga karena stasiun 1 merupakan daerah muara sungai sehingga nilainya lebih rendah dibanding dengan stasiun 2 dan 3. Hasil pengukuran menunjukan salinitas yang didapat pada bulan Januari menunjukkan nilai yang relatif lebih rendah. Salinitas yang rendah pada bulan januari dipengaruhi oleh faktor cuaca, dimana curah hujan setelah pengambilan sampel pertama pada bulan Desember 2020 terus terjadi hujan sehingga menurunkan kadar salinitas pada air laut.

Tabel 1. Pengukuran Parameter Kualitas Perairan Tambak Lorok Bulan Desember 2020, Januari 2021, Maret 2021

\begin{tabular}{|c|c|c|c|c|c|c|c|c|c|c|}
\hline \multirow{2}{*}{ Parameter } & \multicolumn{3}{|c|}{ Desember 2020} & \multicolumn{3}{|c|}{ Januari 2021} & \multicolumn{3}{|c|}{ Maret 2021} & \multirow{2}{*}{ Baku Mutu* } \\
\hline & 1 & 2 & 3 & 1 & 2 & 3 & 1 & 2 & 3 & \\
\hline Suhu $\left({ }^{\circ} \mathrm{C}\right)$ & 30,1 & 31,4 & 30,3 & 28,3 & 29,1 & 30,6 & 30,7 & 31,8 & 32,2 & $28-32$ \\
\hline Salinitas (ppm) & 24,17 & 31,6 & 32,8 & 21,6 & 30,3 & 32,6 & 22,3 & 31,6 & 33,6 & $28-35$ \\
\hline Kecerahan (cm) & 0,5 & 0,6 & 1,2 & 0,4 & 0,5 & 1,0 & 0,5 & 0,7 & 1,25 & $>3$ \\
\hline DO (mg/l) & 1,8 & 5,88 & 6,08 & 1.33 & 4,6 & 6,1 & 1,6 & 5,81 & 7,03 & $>5$ mg/l \\
\hline $\mathrm{Ph}$ & 6,81 & 7,78 & 7,65 & 5,04 & 7,41 & 7,6 & 6,67 & 7,57 & 7,71 & $7-8,5$ \\
\hline Arus (m/s) & 0,053 & 0,031 & 0,05 & 0,18 & 0,05 & 0.04 & 0.13 & 0,05 & 0.04 & \\
\hline Curah Hujan(mm) & 417.3 & & & 300,8 & & & 146,9 & & & \\
\hline
\end{tabular}

Keterangan *) : Keputusan Menteri Lingkungan Hidup No. 51 Tahun 2004 
Tabel 2 . Kandungan logam berat Kadmium (Cd) dalam air di Perairan Tambak Lorok

\begin{tabular}{lllll}
\hline Stasiun Penelitian & Titik & $\begin{array}{l}\text { Desember 2020 } \\
\text { Kadmium }(\mathrm{mg} / \mathrm{l})\end{array}$ & $\begin{array}{l}\text { Januari 2021 } \\
\text { Kadmium }(\mathrm{mg} / \mathrm{l})\end{array}$ & $\begin{array}{l}\text { Maret 2021 } \\
\text { Kadmium }(\mathrm{mg} / \mathrm{l})\end{array}$ \\
\hline \multirow{2}{*}{ Stasiun 1 } & Titik 1 & $<0,001$ & 0,689 & 0,226 \\
& Titik 2 & $<0,001$ & 0,560 & 0,254 \\
& Titik 3 & $<0,001$ & 0,670 & 0,255 \\
\hline \multirow{2}{*}{ Stasiun 2 } & Titik 1 & $<0,001$ & 0,602 & 0,115 \\
& Titik 2 & $<0,001$ & 0,696 & 0,1 \\
& Titik 3 & 0,02 & 0,613 & 0,203 \\
\hline \multirow{3}{*}{ Stasiun 3 } & Titik 1 & 0,01 & 0,552 & 0,193 \\
& Titik 2 & 0,05 & 0,670 & 0,151 \\
Baku mutu & Titik 3 & 1,02 & 0,626 & 0,206 \\
& & $0,01^{*}$ & $0,01^{*}$ & $0,01^{*}$ \\
\hline
\end{tabular}

Keterangan : ${ }^{*}=$ Keputusan Menteri Lingkungan Hidup No. 51 Tahun 2004 untuk perairan pelabuhan; ${ }^{* *}=$ Keputusan Menteri Lingkungan Hidup No. 51 Tahun 2004 untuk biota laut

Kandungan logam berat Kadmium (Cd) dalam sedimen pada bulan Desember 2020, Januari 2021, dan Maret 2021 yang telah dianalisis menunjukkan nilai yang cukup beragam. Kandungan logam berat Kadmium (Cd) dalam sedimen dapat dilihat pada Tabel 3. Hasil keseluruhan konsentrasi logam berat yang didapat pada bulan Januari 2021 cenderung lebihkecil dibandingkan dengan pada bulan Desember 2020 dan bulan Maret 2021, hal ini diduga terjadi karena pada Januari sudah memasuki musim penghujan, pengaruh dari musim penghujan akan menimbulkan gelombang yang besar sehingga logam berat kadmium (Cd) yang mengendap di dalam sedimen mengalami pengenceran oleh air hujan dan sedimen yang mengandung logam berat mengalir terbawa arus menuju lautan lepas. Menurut Supriyantini dan Endrawati (2015), yang mengatakan kandungan logam berat yang terdapat di dalam sedimen dapat dipengaruhi oleh kondisi lingkungan. Kondisi lingkungan yang tenang menyebabkan konsentrasi di dalam sedimen menjadi lebih tinggi, sedangkan pada musim hujan dengan kondisi lingkungan memiliki kecepatan angin yang tinggi dapat menimbulkan gelombang yang tinggi dan partikel partikel sedimen akan teraduk. Hal yang serupa juga didapatkan oleh wardani et al. (2018), konsentrasi logam berat padasedimen di bulan Januari 2016 menunjukkan nilai yang lebih kecil dibandingkan dengan nilai konsentrasi pada bulan April 2015 diduga karena perbedaan faktor cuaca yang menyebabkan sedimen terencerkan dan terbawa oleh arus ke arah laut lepas. Menurut Natsir et al. (2019), Logam berat kadmium (Cd) yang terdapat pada sedimen dapat berasal dari kegiatan antropogenik yang dilakukan oleh masyarakat di sekitar Perairan Tambak Lorok dan juga disebabkan oleh kegiatan lalu lintas kapal yang kemudian terendapkan di dalam sedimen.. Logam berat kadmium (Cd) merupakan logam berat yang berbahaya, logam ini tidak dapat didegradasi oleh organisme dan lingkungan. Keberadaan logam kadmium (Cd) yang semakin banyak di perairan akan terakumulasi dan mengendap pada dasar perairan menyatu dengan sedimen, selain itu kandungan logam berat akan masuk kedalam sistem rantai makanan dan mempengaruhi kehidupan biota yang ada di dalamnya (Arsad et al., 2012).

Berdasarkan hasil analisis kandungan logam berat Kadmium (Cd) yang dilakukan pada bulan Desember 2020 pada 3 stasiun menunjukkan data yang masih berada dibawah nilai ambang batas yang ditetapkan. Bulan Januari 2021 menunjukkan data pada stasiun 1, 2 dan 3 titik 1 yang masih dibawah nilai ambang batas yang ditetapkan sedangkan untuk stasiun 3 titik $2(1,616 \mathrm{mg} / \mathrm{kg})$ dan $3(1,597 \mathrm{mg} / \mathrm{kg})$ telah melebihi nilai ambang batas yang ditetapkan. Hasil analisis kandungan logam berat yang dilakukan pada bulan Maret 2021 cukup tinggi dikarenakan sudah memasuki musim kemarau dan hasil yang didapat ada yang melebihi batas ambang yang ditetapkan yaitu pada stasiun 1 titik $3(1,643 \mathrm{mg} / \mathrm{kg})$, stasiun 2 titik $2(1,700 \mathrm{mg} / \mathrm{kg})$ dan stasiun 3 titik $2(1,823$ $\mathrm{mg} / \mathrm{kg}$ ) dan $3(1,931 \mathrm{mg} / \mathrm{kg})$. baku mutu kandungan logam berat yang telah ditetapkan yaitu 1,5 $\mathrm{mg} / \mathrm{kg}$ menurut ANZECC/ARMACANZ (2000). 
Tabel 3. Kandungan logam berat Kadmium (Cd) dalam sedimen di Perairan Tambak Lorok

\begin{tabular}{ccccc}
\hline $\begin{array}{c}\text { Stasiun } \\
\text { Penelitian }\end{array}$ & Titik & $\begin{array}{c}\text { Desember 2020 } \\
\text { Kadmium }(\mathrm{mg} / \mathrm{kg})\end{array}$ & $\begin{array}{c}\text { Januari 2021 } \\
\text { Kadmium }(\mathrm{mg} / \mathrm{kg})\end{array}$ & $\begin{array}{c}\text { Maret 2021 } \\
\text { Kadmium }(\mathrm{mg} / \mathrm{kg})\end{array}$ \\
\hline \multirow{2}{*}{ Stasiun 1 } & Titik 1 & 1,063 & $<0,001$ & 1,009 \\
& Titik 2 & 1,031 & $<0,001$ & 1,167 \\
& Titik 3 & 0,923 & 0,139 & 1,643 \\
\hline \multirow{2}{*}{ Stasiun 2 } & Titik 1 & 0,911 & 1,058 & 1,394 \\
& Titik 2 & 1,282 & 0,259 & 1,700 \\
& Titik 3 & 1,101 & 0,658 & 1,323 \\
\hline \multirow{2}{*}{ Stasiun 3 } & Titik 1 & 1,015 & 0,278 & 0,855 \\
& Titik 2 & 0,897 & 1,616 & 1,823 \\
\hline Baku mutu* & Titik 3 & 1,148 & 1,597 & 1,931 \\
\hline Ketrangan $^{*}$
\end{tabular}

Keterangan $:{ }^{*}=$ ANZECC and ARMCANZ $2000(1,5 \mathrm{mg} / \mathrm{kg})$.

Kandungan logam berat Kadmium (Cd) dalam jaringan lunak kerang hijau pada bulan Desember 2020, Januari 2021, dan Maret 2021 yang telah dianalisis menunjukkan nilai yang cukup beragam. Kandungan logam berat Kadmium (Cd) dalam jaringan lunak kerang hijau dapat dilihat pada Tabel 4.

Hasil analisis kandungan logam berat kadmium (Cd) dalam jaringan lunak kerang hijau (Perna viridis) yang diambil pada bulan Januari 2021 menunjukkan nilai yang cenderung lebih besar dibandingkan dengan hasil analisis yang dilakukan pada bulan Desember 2020 dan Maret 2021. perbedaan tinggi konsentrasi bisa diduga karena perbedaan cuaca pada saat pengambilan sampel. Sampel yang diambil pada bulan Januari 2021 telah memasuki musim penghujan sehingga partikel yang mengendap teraduk dan terangkat ke kolom perairan. Hal ini sejalan dengan penelitian Nurhayati dan Putri (2019), yang menyatakan pada musim hujan terjadi pergerakan arus yang kuat dan partikel logam berat yang mengendap terangkat ke kolom perairan. Kosentrasi yang tersebar pada kolom perairan selanjutnya akan diserap oleh keranghijau (Astari et al., 2021). Sedangkan berdasarkan stasiun nilai yang cenderung lebih besardidapat pada stasiun 3 (Pelabuhan) hal ini diduga karena terdapat pengaruh parameter kualitas perairan seperti suhu dan juga $\mathrm{pH}$. Menurut Sijabat et al. (2014), kondisi suhu yang tinggi dapat meningkatkan daya toksisitas pada logam berat. Sedangkan nilai $\mathrm{pH}$ yang tinggi dapat mengakibatkan logam berat yang ada diperairan menjadi terlarut dan melayang di perairan dan akhirnya masuk ke dalam tubuh kerang hijau. Berdasarkan parameter kualitas perairan didapat suhu dan $\mathrm{pH}$ di stasiun 3 lebih tinggi dibanding dengan stasiun lainnya hal ini diduga menjadi tingginya kandungan logam berat pada jaringan lunak kerang hijau.

Hasil nilai kandungan logam berat kadmium $(\mathrm{Cd})$ yang terdapat dalam jaringan lunakkerang hijau (Perna viridis) pada bulan Desember 2020 menunjukkan bahwa setiap stasiun dan titiknya memiliki nilai yang masih berada di bawah ambang batas dari baku mutu yang telah ditetapkan. Sedangkan pada bulan Januari 2021 stasiun 1 titik $2(1,693 \mathrm{mg} / \mathrm{kg})$ dan stasiun 3 titik $1(1,265 \mathrm{mg} / \mathrm{kg})$ dan $2(1,120 \mathrm{mg} / \mathrm{kg})$ telah melebihi ambang batas yang ditetapkan dan bulan Maret 2021 hasil kandungan logam berat kadmium (Cd) pada stasiun 1 titik $3(1,157 \mathrm{mg} / \mathrm{kg})$ dan stasiun3 titik 2 $(1,411 \mathrm{mg} / \mathrm{kg})$ dan $3(1,611 \mathrm{mg} / \mathrm{kg})$ telah melebihi batas ambang yang telah ditentukan. Nilai baku mutu yang telah ditetapkan berdasarkan Badan Standarisasi Nasional melalui SNI 7387:2009 tentang batas cemara logam berat pada pangan yaitu sebesar $1,0 \mathrm{mg} / \mathrm{kg}$.

Faktor Biokonsentrasi (BCF) digunakan untuk mengetahui kemampuan daya serap kerang hijau atau untuk mengetahui kemampuan kerang hijau dalam mengakumulasi logam berat Kadmium (Cd) dalam air laut. Data bioakumulasi logam berat Kadmium (Cd) di Perairan Tambak Lorok dari media air dapat dilihat pada Tabel 5. 
Tabel 4. Kandungan logam berat Kadmium (Cd) dalam jaringan lunak kerang hijau di Perairan Tambak Lorok

\begin{tabular}{ccccc}
\hline $\begin{array}{c}\text { Stasiun } \\
\text { Penelitian }\end{array}$ & Titik & $\begin{array}{c}\text { Desember 2020 } \\
\text { Kadmium }(\mathrm{mg} / \mathrm{kg})\end{array}$ & $\begin{array}{c}\text { Januari 2021 } \\
\text { Kadmium }(\mathrm{mg} / \mathrm{kg})\end{array}$ & $\begin{array}{c}\text { Maret 2021 } \\
\text { Kadmium }(\mathrm{mg} / \mathrm{kg})\end{array}$ \\
\hline \multirow{2}{*}{ Stasiun 1 } & Titik 1 & 0,070 & 0,759 & 0,599 \\
& Titik 2 & 0,250 & 1,693 & 0,532 \\
& Titik 3 & 0,470 & 0,474 & 1,157 \\
\hline \multirow{2}{*}{ Stasiun 2 } & Titik 1 & 0,286 & 0,488 & 0,491 \\
& Titik 2 & 0,262 & 0,681 & 0,586 \\
& Titik 3 & 0,224 & 0,798 & 0,403 \\
\hline \multirow{2}{*}{ Stasiun 3 } & Titik 1 & 0,942 & 1,265 & 0,576 \\
& Titik 2 & 0,655 & 1,120 & 1,411 \\
& Titik 3 & 0,744 & 0,629 & 1,611 \\
\hline Baku mutu & & 1,0 & 1,0 & 1,0 \\
\hline
\end{tabular}

Keterangan : ${ }^{*}=$ SNI 7387:2009 (batas cemaran logam berat pada pangan) $(1,0 \mathrm{mg} / \mathrm{kg}$ )

Tabel 5. Faktor Biokonsentrasi Logam Berat Kadmium (Cd) Biota dengan Air di Tambak Lorok

\begin{tabular}{ccccc}
\hline \multirow{2}{*}{ Stasiun Penelitian } & Titik & Desember 2020 & Januari 2021 & Maret 2021 \\
\cline { 3 - 5 } & Titik 1 & Kadmium (BCF) & Kadmium (BCF) & Kadmium (BCF) \\
\hline \multirow{2}{*}{ Stasiun 1 } & Titik 2 & - & 1,101 & 2,650 \\
& Titik 3 & - & 3,023 & 2,094 \\
& Titik 1 & - & 0,707 & 4,537 \\
Stasiun 2 & Titik 2 & - & 0,810 & 4,269 \\
& Titik 3 & 11,2 & 0,978 & 5,86 \\
& Titik 1 & 94,2 & 1,301 & 1,985 \\
Stasiun 3 & Titik 2 & 13,1 & 2,291 & 2,984 \\
& Titik 3 & 0,729 & 1,671 & 9,344 \\
Kadar Rendah & & $<100$ & 1,004 & 7,820 \\
Kadar sedang & & $100-1000$ & $<100$ & $<100$ \\
Kadar Tinggi & & $>1000$ & $100-1000$ & $100-1000$ \\
\hline
\end{tabular}

Nilai faktor biokonsentrasi yang didapat menunjukkan kecenderungan penyerapan logam berat lebih banyak terjadi pada air. Hal ini juga diperkuat oleh Astari et al. (2021), kerang hijau lebih mudah mengakumulasi logam berat yang terkandung dalam media air dikarenakan oleh sifat dasar kerang hijau, yaitu filter feeder yang memperoleh makanannya dari hasil penyaringan partikelpartikel yang berasal dari air laut dan juga habitat kerang hijau yang menempel pada batu, atau bambu di kolom perairan. Akumulasi logam berat Kadmium (Cd) yang terkandung dalam jaringan lunak kerang hijau dari Perairan Tambak Lorok perlu untuk diwaspadai dan dikontrol dalam jumlah konsumsi setiap harinya, sehingga tidak menimbulkan efek yang buruk. Efek racun yang dapat ditimbulkan seperti kerusakan pada paru, ginjal, hati, dan tulang (Andayani et al., 2020)

Estimated daily intake merupakan suatu perkiraan estimasi asupan logam berat yangmasuk ke dalam tubuh manusia melalui konsumsi makanan pada setiap harinya (Rayyan et al., 2019). Perhitungan Estimated daily intake dapat dilihat pada Tabel 6 dan 7. Perhitungan EDImenggunakan ketentuan untuk laki-laki dewasa dengan berat badan rata-rata $60 \mathrm{~kg}$ (Nuraini et al., 2017) yang mengkonsumsi kerang hijau sebanyak $54 \mathrm{~g}$ per hari selama 30 tahun yang mendeskripsikan perkiraan lama terjadinya pajanan dan 70 tahun menyatakan periode waktuuntuk efek karsinogenik (Depkes, 2012) berada pada kisaran antara $0,000026 \mathrm{mg} / \mathrm{kg}$ sampai $0,000626 \mathrm{mg} / \mathrm{kg} / \mathrm{hari}$. Berdasarkan data yang didapat pada Tabel 8. Nilai EDI atau estimasiasupan harian untuk logam 
berat Cd untuk laki-laki dewasa pada bulan Desember 2020, Januari 2021, dan Maret 2021 seluruhnya masih berada dibawah batas maksimum yang ditetapkan oleh US EPA (1985).

Hasil yang hampir serupa juga didapat pada nilai EDI untuk perempuan dewasa dengan berat badan rata-rata $45 \mathrm{~kg}$ (Nuraini et al., 2017) yang mengkonsumsi kerang hijau sebanyak $54 \mathrm{~g}$ per hari selama 30 tahun yang mendeskripsikan perkiraan lama terjadinya pajanan dan 70 tahun menyatakan periode waktu untuk efek karsinogenik (Depkes, 2012). Berdasarkan hasil perhitungan didapat nilai EDI pada kisaran $0,000035 \mathrm{mg} / \mathrm{kg}$ sampai $0,000835 \mathrm{mg} / \mathrm{kg} / \mathrm{hari}$. Nilai EDlatau estimasi asupan harian untuk logam berat Cd untuk perempuan dewasa pada bulan Desember 2020, Januari 2021, dan Maret 2021 seluruhnya masih berada dibawah batas maksimum yang ditetapkan oleh US EPA (1985). Nilai yang telah ditetapkan oleh US EPA (1985) yaitu 0,001 mg/kg/hari.

Nilai Target Hazard Quotient (THQ) digunakan untuk mengetahui tingkat risiko yang dapat menimbulkan bahaya terhadap manusia terutama oleh dampak karsinogen. Nilai THQ dapat dilihat pada Tabel 8 dan 9. Berdasarkan hasil perhitungan THQ pada kerang hijau untuk laki-laki dewasa di Perairan Tambak Lorok, Kota Semarang. Berdasarkan data yang diperoleh pada bulan Desember 2020, Januari 2021, dan Maret 2021 sebesar 0,026 sampai 0,626. Hasil THQ seluruhnya menununjukkan angka kurang dari 1 sehingga tidak dapat menyebabkan efek karsinogen pada manusia yang mengkonsumsinya.

Hasil yang hampir serupa juga didapat dengan menghitung THQ pada perempuan dewasa di Perairan Tambak Lorok, Kota Semarang. Berdasarkan data yang diperoleh pada bulan Desember 2020, Januari 2021, dan Maret 2021 menunjukkan nilai berkisar 0,035 sampai 0,835. Hasil THQ seluruhnya menununjukkan angka kurang dari 1 sehingga tidak dapat menyebabkan efek karsinogen pada manusia yang mengkonsumsinya.

Tabel 6. Estimasi Asupan Harian (EDI) Logam Berat Cd dalam Kerang Hijau untuk laki laki Dewasa

\begin{tabular}{cccc}
\hline Bulan & Stasiun & $\begin{array}{c}\text { EDI (rata-rata) } \\
\mathrm{mg} / \mathrm{kg} / \mathrm{hari}\end{array}$ & $\begin{array}{c}\text { PMTDI } \\
\text { (ProvisionalMaximum Tolerable Daily Intake) }\end{array}$ \\
\hline \multirow{2}{*}{ Desember2020 } & 1 & 0.000097 & \\
& 2 & 0.000095 & \\
Januari2021 & 3 & 0.000288 & \\
& 1 & 0.000361 & $0.001 \mathrm{mg} / \mathrm{kg} / \mathrm{hari}(\mathrm{US}$ EPA, 1985) \\
Maret2021 & 3 & 0.000242 & \\
& 1 & 0.000372 & \\
& 2 & 0.000282 & \\
& 3 & 0.000183 & \\
\hline
\end{tabular}

Tabel 7. Estimasi Asupan Harian (EDI) Logam Berat Cd dalam Kerang Hijau Perempuan Dewasa

\begin{tabular}{cccc}
\hline Bulan & Stasiun & $\begin{array}{c}\text { EDI (rata-rata) } \\
\mathrm{mg} / \mathrm{kg} / \mathrm{hari}\end{array}$ & $\begin{array}{c}\text { PMTDI } \\
\text { (ProvisionalMaximum Tolerable Daily Intake) }\end{array}$ \\
\hline \multirow{2}{*}{ Desember2020 } & 1 & 0.000130 & \\
& 2 & 0.000127 & \\
Januari2021 & 3 & 0.000385 & \\
& 1 & 0.000481 & $0.001 \mathrm{mg} / \mathrm{kg} / \mathrm{hari}($ US EPA, 1985) \\
Maret2021 & 3 & 0.000324 & \\
& 1 & 0.000495 & \\
& 2 & 0.000376 & \\
\hline
\end{tabular}


Tabel 8. Target Hazard Quotient (THQ) Logam Berat Cd dalam Kerang Hijau untuk Laki-laki Dewasa

\begin{tabular}{ccc}
\hline Bulan & Stasiun & THQ (Rata-rata) \\
\hline \multirow{2}{*}{ Desember2020 } & 1 & $0,097 \pm 0,074$ \\
& 2 & $0,095 \pm 0,012$ \\
Januari2021 & 3 & $0,288 \pm 0,054$ \\
& 1 & $0,361 \pm 0,236$ \\
Maret2021 & 2 & $0,242 \pm 0,058$ \\
& 3 & $0,372 \pm 0,123$ \\
& 1 & $0,282 \pm 0,127$ \\
& 2 & $0,183 \pm 0,034$ \\
\hline
\end{tabular}

Keterangan : THQ $<1$ (Yap et al., 2016)

Tabel 9. Target Hazard Quotient (THQ) Logam Berat Cd dalam Kerang Hijau untuk Perempuan Dewasa

\begin{tabular}{ccc}
\hline Bulan & Stasiun & THQ (Rata-rata) \\
\hline \multirow{2}{*}{ Desember2020 } & 1 & $0,130 \pm 0,099$ \\
& 2 & $0,127 \pm 0,016$ \\
Januari2021 & 3 & $0,385 \pm 0,073$ \\
& 1 & $0,481 \pm 0,314$ \\
Maret2021 & 2 & $0,324 \pm 0,077$ \\
& 3 & $0,495 \pm 0,164$ \\
& 1 & $0,376 \pm 0,170$ \\
& 2 & $0,730 \pm 0,045$ \\
\hline
\end{tabular}

Nilai THQ yang berada dibawah 1 tersebut tidak berarti dalam mengkonsumsi kerang hijau sudah aman sepenuhnya. Logam berat yang diuji adalah logam berat cadmium (Cd) yang termasuk ke dalam golongan logam berat non esensial yang tidak dibutuhkan oleh tubuh. Kadmium yang masuk ke dalam tubuh dapat merusak organ dan menghambat pertumbuhan, perkembangan, dan menurunkan imun tubuh. Efek jangka panjang yang ditimbulkan dapat merusak paru-paru, hati, ginjal, dan tulang (Istarani dan Pandebesie, 2014).

\section{KESIMPULAN}

Kandungan logam berat kadmium (Cd) dalam air bulan Desember 2020 pada stasiun 2 titik 3 dan seluruh titik pada stasiun 3 telah melebihi baku mutu yang telah ditetapkan, sedangkan pada bulan Januari 2021 dan Maret 2021 seluruhnya melebih baku mutu yang ditetapkan. Logam berat pada sedimen bulan Januari 2021 stasiun 3 titik 2 dan 3, bulan Maret 2021 stasiun 1 titik 3, stasiun 2 titik 2 dan stasiun 3 titik 2 dan 3 telah melebihi baku mutu yang ditetapkan dan jaringan lunak kerang hijau (Perna viridis) bulan Januari 2021 stasiun 1 titik 2 dan stasiun 3 titik 1 dan 2, bulan Maret 2021 stasiun 1 titik 3 dan stasiun 3 titik 2 dan 3 telah melebihi baku mutu yang ditetapkan. Faktor biokonsentrasi sampel kerang hijau (Perna viridis) pada sampel air dan sedimen menunjukkan nilai kurang dari $100(<100)$ pada semua titik stasiun sehingga termasuk ke dalam kategori rendah. Penilaian risiko kesehatan dihitung dengan THQ, berdasarkan data yang didapat nilai THQ pada bulan Desember 2020, Januari 2021, dan Maret 2021 seluruhnya menunjukkan angka kurang dari 1 yang artinya dalam mengkonsumsi kerang hijau tidak menimbulkan potensi efek karsinogenik pada tubuh. 


\section{DAFTAR PUSTAKA}

Adhani, R. \& Husaini. 2017. Logam Berat Sekitar Manusia. Banjarmasin : Universitas Lambung Mangkurat.

Anam, K., Idris, F., \& Syakti, A.D. 2019. Analisis Kandungan Logam Berat Pb dan Cd pada siput Gonggong (Strombus sp) di Perairan Kecamatan Bukit Bestari. Jurnal Buana Sains, 19(1):37-46

Andayani, A., Koesharyani, I., Fayumi, U., Rasidi, \& Sugama, K. 2020. Akumulasi Logam Berat Pada Kerang Hijau di Perairan Pesisir Jakarta. Oseanologi dan Limnologi di Indonesia, 5(2):135-144.

Arsad, M., Said, I. \& Suherman. 2012. Akumulasi Logam Timbal (Pb) dalam Ikan Belanak (Liza melinoptera) yang Hidup di Muara Poboya. Jurnal Akademika Kimia, 1(4):187-192.

Astari, F.N., Batu, D.T.F.L. \& Setyobudiandi, I. 2021. Akumulasi Besi (Fe) pada Kerang Hijau di Perairan Tanjung Mas, Semarang. Jurnal IImu Pertanian Indonesia, 26 (1):120-127.

Australian and New Zealand Environment and Conservation Council (ANZECC). 2000. ANZECC interim sediment quality guidlines. Report for the Environmental Research Institute of the Supervising Scientist, Sydney, Australia.

Badan Meteorologi, Klimatologi, dan Geofisika (BMKG). 2021. Data Online Pusat Database - BMKG. dataonline.bmkg.go.id

Badan Standardisasi Nasional. 2009. SNI 7387:2009. Batas Maksimum Cemaran Logam Berat dalam Makanan. BSN RI, Jakarta.

Departemen Kesehatan. 2012. Pedoman Analisis Risiko Keseatan Lingkungan.

Effendi, H. 2003. Telaah Kualitas Air bagi Pengelolaan Sumberdaya dan Lingkungan Perairan.

Eshmat, M.E., Mahasri, G. \& Rahardja, B.S. 2014. Analisis Kandungan Logam Berat Timbal (Pb) dan Kadmium (Cd) pada Kerang Hijau (Perna viridis L.) di Perairan NgembohKabupaten Gresik Jawa Timur. Jurnal Ilmiah Perikanan dan Kelautan, 6(1):101-108.

Istarani, F. \& Pandebesie, E.S. 2014. Studi Dampak Arsen (As) dan Kadmium (Cd) terhadap Penurunan Kualitas Lingkungan. Jurnal Teknik Pomits, 3(1):53-58.

Kama, N.A., Ansar, R.A. \& Akbar, M.N. 2020. Efektivitas Bubur Rumput Laut Sebagai Reduktor Logam Timbal pada Kerang Hijau. Jurnal Sosial Budaya dan Sains, 2(1):11-18.

KepMen LH, 2004,. Keputusan Mentri Negara Lingkungan Hidup no 51 tahun 2004 tentang Baku Mutu Air Laut. Mentri Negara Lingkungan Hldup, Jakarta

Khusnia, A.Z., Astorina, N. \& Rahardjo, M. 2019. Indek Pencemaran Lingkungan Secara FisikaKimia dan Biokonsentrasi Timbal (Pb) pada Kerang Hijau di perairan Pesisir Semarang Utara. Jurnal Prespitasi, 16(2):40-47.

La Grega, M.D., Buckingham, P.L., Evans, J.C.. 2001. Hazardous Waste Management. 2 nd edition. Boston (MA): McGraw-Hill.

Mamoribo, H., Rompas, R.J. \& Kalesaran, O.J. 2015. Determinasi Kandungan Kadmium (Cd)di Perairan Pantai Malalayang Sekitar Rumah Sakit Prof Kandou Manado. Jurnal Budidaya Perairan, 3 (1) 114-118.

Natsir, N.A., Hanike, Y., Rijal, M., \& Bachtiar, S. 2019. Kandunga Logam berat Timabl (Pb) dan Kadmium (Cd) pada Air, Sedimen, dan Organ Mangrove di Perairan Tulehu. Journal of Biology Science and Education, 8(2):149-159.

Noviansyah, E., Batu, D.T.F.L. \& Setyobudiandi, I. 2021. Kandungan Logam Kadmium (Cd) pada Air Laut, Sedimen, dan Kerang Hijau di Perairan Tambak Lorok dan Perairan Morosari. Jurnal IImu Pertanian Indonesia, 26(1):128-135.

Nuraini, R.A.T., Endrawati, H., \& Maulana, I.R. 2017. Maulana. Analisis Kandungan Logam Berat Kromium (Cr) pada Air, Sedimen, dan Kerang Hijau (Perna viridis) di Perairan Trimulyo Semarang. Jurnal Kelautan Tropis, 20(1):48-55.

Nurhayati, D. \& Putri, D.A.. 2019. Bioakumulasi Logam Berat pada Kerang Hijau (Perna viridis)di Perairan Cirebon Berdasarkan Musim yang Berbeda. Jurnal Akuatika Indonesia, 4(1):6-10.

Patty, S.I. 2013. Distribusi Suhu, Salinitas, dan Oksigen Terlarut di Perairan Kema, Sulawesi Utara. Jurnal IImiah Platax, 1(3):148-157.

Prihati, S.R., Suprapto, D. \& Rudiyanti, S. 2020. Kadar Logam Berat Pb, Fe, dan Cd yang Terkandung dalam Jaringan Lunak Kerang Batik (Paphia undulata) dari Perairan TambakLorok, Semarang. Jurnal Pasir Laut, 4 (2) : 116-123.

Rachmaningrum, M., Wardhani, E. \& Pharmawati, K. 2015. Konsentrasi Logam Berat Kadmium (Cd) pada Perairan Sungai Citarum Hulu Segmen Dayeuhkolot-Nanjung. Jurnal Rekayasa Lingkungan, 3(1):1-10. 
Rayyan, M.F., Yona, D. \& Sari, S.H.J. 2019. Health Risk Assessment of Heavy Metals of Perna viridis from Banyuurip Waters in Ujung Pangkah, Gresik. Journal of Fisheries and Marine Research, 3(2):135-143.

Sijabat, E., Trinuraini, R. A., \& Supriyantini, E. (2014). Kandungan logam berat timbal (Pb) pada air, sedimen, dan kerang hijau (Perna viridis) di Perairan Tanjung Emas Semarang. Journal of Marine Research, 3(4):475-482.

Soegianto, A., Putranto, T.W.C., Lutfi, W., Almiranti, F.N., Hidayat, A.R., Muhammad, A., Firdaus, R.A., Rahmadhani, Y.S., Fadila, D.A.N. \& Hidayati, D. 2020. Concentrations of Metals in Tissues of Cockle Anadara granosa (Linnaeus, 1758) from East Java Coast, Indonesia, and Potential Risks to Human Health. Hindawi International Journal of Food Science., p1-9.

Sugiyono. 2017. Metode Penelitian Kuantitatif, Kualitatif, dan R\&D. Alfabeta, Bandung.

Sundra, I.K. 2006. Kualitas Air Bawah Tanah di Wilayah Pesisir Kabupaten Bandung. Jurnal IImu Lingkungan, 1(2):1-13.

Supriyantini, E. \& Endrawati, H. 2015. Kandungan Logam Berat Besi (Fe) Pada Air, Sedimen, dan Kerang Hijau (Perna viridis) Di Perairan Tanjung Emas Semarang. Jurnal Kelautan Tropis. 18(1): 38-48.

Susana, T. 2009. Tingkat Keasaman $(\mathrm{pH})$ dan Oksigen Terlarut sebagai Indikator Kualitas Perairan Sekitar Muara Sungai Cisadane. Jurnal Teknik Lingkungan, 5(2):33-39.

Triantoro, D.D., Suprapto, D. \& Rudiyanti, S. 2017. Kadar Logam Berat Besi (Fe), Seng (Zn) pada Sedimen dan Jaringan Lunak Kerang Hijau (Perna viridis) di Perairan Tambak Lorok Semarang. Jurnal Manajemen Sumber Daya Perairan, 6(3):173-180.

U.S. EPA. 1985. Updated Mutagencity and Carcinogencity Assessment of Cadmium. Addendum to the Health Assessment Document for Cadmium (EPA 600/B- B1-023). EPA 600/B-83- 025F.

Wardani, I., Ridlo, A. \& Supriyantini, E. 2018. Kandungan Kadmium (Cd) dalam Air, Sedimen, dan Kerang Hijau (Perna viridis) di Perairan Trimulyo Semarang. Journal of Marine Research, 7(2):151-158.

Wulanningrum, S.D. \& Jayanti, T.B. 2016. Evaluasi Kondisi Eksisting Kawasan Tambak Lorok untuk Penerapan Konsep Minapolitan. Jurnal Pengembangan Kota, 4(1):21-28. 